\title{
Efficiency of Using Research and Development Expenditures at Voivodship Level
}

\begin{abstract}
One of the most important criteria dividing countries on developed and developing is technological level of the economy which is a derivative of R\&D. We showed in the article, that only a rather small group of voivodships was characterized by a full efficiency of converting the expenditure into effects. Low values of efficiency indices pay attention for all ineffective provinces. It won't be possible to say about none of them, that it found near the efficiency border which accompanied by large differences between decision making units.

The non-radial DEA model showed that both the internal expenditures (in converting into the thousand residents) and the personnel employed in the R+D work are not used efficiently and what's more in the considerable degree wherein a first of said inputs research units managed by a little more effectively.
\end{abstract}

Key words: research and development, DEA method, efficiency, non-radial efficiency.

\section{Introduction}

One of the main criteria for dividing countries into developed and developing ones is technological development of their economies resulting from carried out research and development activity (also referred to as R\&D). A more developed economy is characterized by greater saturation with modern technical means of production and smaller share of simple jobs based on the use of labour force. 
A characteristic feature of research and development activity in Poland is strong participation of the state budget through financing universities and research institutes. Eventually, however, businesses have started to take part in that process, including those in the group of small and medium enterprises. In total, all entities managing or supervising research projects have quite considerable financial and human resources at their disposal.

Nevertheless, there is still a substantial difference in the volume of expenditures made on research and development between Poland and highly developed countries. Disproportions in the use of expenditures can also be observed at the level of Polish regions. This article will point out the voivodships which are more efficient in using research and development expenditures than other voivodships of the country. It will be proved how significant are departures from optimum efficiency by using the DEA method.

The R\&D potential is usually assessed by means of indices and/or measures expressed as absolute and relative values. In order to prove the proposed hypothesis, the study will use the DEA method which compares all objects with one another and enables to indicate those most efficient taking into account a whole set of factors. Thus, the method is an interesting supplement to traditional analyses.

\section{Research and Development in Poland - Statistical Analysis}

We will quote a definition of research and development activity applied by the Polish Central Statistical Office (CSO). The research and development activity comprises creative work undertaken on a systematic basis in order to increase the stock of knowledge, including knowledge of man, culture and society, and the use of that stock of knowledge to devise new applications. It includes three types of research: basic research, applied research and experimental development [Science and Technology in 2012, p. 34].

In Poland R\&D activity is conducted by various research institutes (including those of the Polish Academy of Sciences - PAS), higher education institutions and entities associated with enterprises, i.e. carrying out scientific and developmental works along with their basic activity. The dynamic development of research activity in Poland is, in our opinion, hampered by: limited cooperation of the industry with purely scientific institutions, including universities, and great dependence of the latter on state subsidies which, compared to the other EU countries, are not generous, which will be further discussed in the article.

"The Report on the Biggest Research and Development Investors in Poland" [p. 7] says that: "the problem of investing in knowledge (...) has been 
a challenge the economic policy has not been able to cope with for over 20 years". The authors of the report mention the following causes of the situation: unfinished transformation and overregulation of academic and research sectors as well as the lack of links between companies with Polish and foreign capital. Moreover, the applicable Accounting Act hinders monitoring R\&D expenditures at the national level [p. 20].

Although the dynamics of investments made by enterprises in Poland is indeed above the EU mean [The Report on the Biggest (...) p. 12], it exceeds by only 0.2 percentage point a rise in public expenditures. Therefore, the authors of the report draw a conclusion that no significant structural changes in the relationship between public and business investments should be expected in the immediate future. Despite the inflow of funds from the EU, Poland fell into the lowest group in respect of assessed innovativeness in Europe.

Contrary to appearances, it is not only Poland that contends with insufficient R\&D investments. In the 2012 ranking of businesses with the biggest investments in R\&D, EU companies accounted for less than $30 \%$ of the first hundred. Certain consolation can be found in the fact that world ranking leaders invest in Poland, which provides access to state-of-the-art technologies and enables to shorten the distance between Poland and the most developed countries.

Interesting conclusions about the involvement of Polish companies in research and development activity were reached by Adamczyk [Adamczyk 2013]. Based on the results of his research it can be pointed out that the share of unsuccessful R\&D projects did not exceed $10 \%$ of all undertaken ones. The risk of failure was lower for large enterprises. It is difficult to decide whether it resulted from lesser experience of small and medium enterprises or their greater propensity for risk. The author of the study also drew attention to the duration of projects. It transpires that over $75 \%$ of projects were completed within up to 3 years with smaller enterprises deciding on shorter-term projects.

An important feature of $\mathrm{R} \& \mathrm{D}$ activity is the period of the economic utility of results. It is affected by the field of research, competition of other enterprises or scientific activity of e.g. a university. The longer the period of the economic utility of research results, the easier to discount the risk of a project. The prospect for making a profit of research results in years to come may be a risk reducing factor in the opinion of potential investors.

According to the theory of finance, a reward for a higher investment risk should be a higher rate of return. As already mentioned, investment in R\&D ought to be considered very risky. On the other hand, results of the quoted 
polls indicate that the possibility of making a loss on research and development activity was not high. Half of the firms obtained the rate of return not exceeding $7.71 \%$. The highest rates of return were received by the largest entities.

The most prominent feature of research and development projects is a large (about 50\%) share of expenditures on staff remuneration as carrying out research activity entails, first and foremost, the need to employ appropriately qualified personnel. The higher the qualifications, the higher expectations about salaries.

The results of those people's work are not necessarily only tangible but also intangible assets whose value is quite measurable. Thus, the recent considerable interest in the protection of copyright, patents, trade marks etc. It sometimes, however, takes a grotesque form, called patent trolling, i.e. registering with patent offices everything which allows to make a profit of selling a licence in the future.

The report "Science and Technology in 2012", published in 2013 and prepared, as the above-mentioned survey, by the Statistical Office in Szczecin, describes the situation of research and development activity in Poland in 2012 taking into account its financing and achieved results. The report states that domestic expenditures on R\&D were at PLN 14.4 billion in 2012, which meant a $22.8 \%$ increase as compared to 2011 . R\&D intensity, i.e. the share of domestic expenditures in GDP, was $0.9 \%$ (as compared to $0.6 \%$ in 2011). Poland ranked nineteenth in the EU in terms of that index, which was 2.7 times lower than that for the whole EU. R\&D expenditures in Poland accounted for $1.29 \%$ of expenditures of the entire EU. Hence, it can be observed that the importance of such activity in Poland is increasing but there is still a large distance between Poland and the most developed European countries. That, regrettably, is the result of many years' neglect of financing science.

The share of enterprises in expenditures was $37.2 \%$, the share of the state sector (PAS and research institutes) was $28 \%$ and that of higher education institutions $-34.4 \%$. Taking into consideration solely public universities, R\&D expenditures were made by $79.5 \%$ of them. Among non-public higher education institutions, the percentage was $31.7 \%$. Such a vast disproportion should not come as a surprise as non-public higher education institutions focus mainly on teaching. Research and development activity, as more risky and expensive, is usually limited by them to a level necessary to obtain accreditation. The rest of expenditures were incurred by non-commercial institutions $(0.4 \%)$. 
The main source of research financing was funds from the state budget (51.4\% of total domestic expenditures). They accounted for $79.9 \%$ of all funds in the state sector and $72.1 \%$ in the case of higher education institutions. In turn, that share was at $11.2 \%$ in the business sector.

The number of individuals employed in research and development activity was 139.7 thousand in 2012 (a rise of 3.8\% as compared to 2011) including 103.6 thousand science and research workers (an increase of $2.9 \%$ as compared to the preceding year). $72.6 \%$ of all individuals working in the R\&D sector were employed in state and local government institutions with the share of science and research workers at $76.3 \%$.

For many years now the basic group of research and development staff in Poland have been employees of public universities. In turn, they very strongly depend on state funds, which is difficult to be considered beneficial in the longer term. The deteriorated situation of the state budget usually results in cuts whose victim is usually science. A solution would be to extend cooperation with the industry but that still remains limited.

In 2012 there were only 5.8 individuals employed in $R \& D$ per 1000 of the total working population. That rate is 12.2 in the EU, which puts Poland very low in the ranking. It should also be emphasized that the share has remained at a similar level in our country for a few years now.

Non-commercial, local government institutions etc. account for a tiny percentage of R\&D employment. In the business sector, $97.4 \%$ of all the employed in R\&D worked directly in enterprises. As it can be seen, enterprises tend to use their own resources. In the state sector, the percentage was even higher $-99.3 \%$ of all the employed. In public higher education institutions, $92.1 \%$ of workers were concerned with research and development. The rest were employed with non-public higher education institutions and entities collaborating with enterprises.

Polish enterprises usually transfer technologies through the purchase of licences. $3.6 \%$ of companies decided to do that as compared to $1.6 \%$ which counted on research and development activity. The purchase of a licence is a faster and easier way of improving technological development of production. Polish companies' expectations of making a profit as quickly as possible do not create favourable conditions for time-consuming research.

In 2012, the Patent Office of the Republic of Poland received 4,410 applications concerning domestic inventions (an increase of $13.7 \%$ as compared to 2011$)$ and awarded 1,848 patents for domestic inventions $(7.1 \%$ less than a year earlier). Moreover, 941 domestic utility models were submitted for registration (940 in 2011). Protection rights were granted for 514 models (a rise 
of 3.2\% from year to year). Among applications filed with the Patent Office, $47.7 \%$ came from PAS scientific units, research institutes and higher education institutions.

In 2012, considerable regional diversification was observed in Poland in terms of research and development activity. Relevant indices tended to be the highest for the Mazowieckie voivodship. It was where 33.6\% of direct budgetary subsidies went. In the territory of the Mazowieckie voivodship, there were 693 entities, i.e. one-fourth of all research active entities and $39.5 \%$ of the total number of scientific and R\&D ones. In the second in the ranking, the Śląskie voivodship, there were 335 such entities, while in the lowest ranking Lubuskie voivodship - only 37.

The share of research and development expenditures in GDP varied substantially among voivodships: from $0.17 \%$ for the Lubuskie to $1.37 \%$ for the Mazowieckie voivodships. Expenditures per capita in the Lubuskie voivodship were PLN 55, whereas in the Mazowieckie voivodship they reached PLN 887 with the national rate at PLN 303.

However, the biggest share of funds from the business sector was noted in the Podkarpackie (65.4\%) and Śląkie (44.6\%) voivodships. The Mazowieckie voivodship ranked seventh in that respect. Hence, it used budgetary financing and EU funds to an extent resulting in decreased interest in obtaining money from other sources. The rate for the whole Poland was 32.3\%.

Similarly to domestic expenditures, also employment in the research and development sector varied markedly among voivodships. Certainly, the biggest number of individuals worked in the Mazowieckie voivodship - as much as $30.3 \%$. The rate of personnel employed in research and development per 1000 of the total working population was, thus, $11.2 \%$ for that voivodship. The second in that ranking, the Małopolskie voivodship, showed a rate of $8.7 \%$, while it was $5.8 \%$ on the scale of the whole country. The lowest in the ranking were Świętokrzyskie $(0.6 \%)$ and Lubuskie $(0.9 \%)$ voivodships. Interestingly, the share of science and research personnel in the total R\&D personnel in 2012 was the highest in the Lubuskie $-91.4 \%$ and Podlaskie - 90.7\% voivodships. The Mazowieckie voivodship with its $65.4 \%$ ranked even below the country's average of $73.9 \%$.

Voivodships also differed in results measured by numbers of submitted patent and utility model applications. The largest numbers of applications per 1 million of the population came from the Mazowieckie (184.2 patent applications), Dolnośląskie (157.1) and Łódzkie (130.5) voivodships. The smallest numbers of applications originated from the Świętokrzyskie (54.9 patents), Podkarpackie (48.4 patents) and Lubuskie (45.9) voivodships. Additionally, it 
should be taken into consideration that $17.4 \%$ of applicants had their registered offices in the territory of the Mazowieckie voivodship.

\section{Description of Expenditures and Results}

The concept of efficiency is not new to economics but it is usually presented as a relationship of an individual result to an individual expenditure. In the 1970s (compare: Charnes, Cooper, Rhodes [1978] the concept called Data Envelopment Analysis (DEA) appeared.

The method is based on the relationship of the weighted sum of expenditures and the weighted sum of results determined separately for each of analysed units, the so called Decision Making Units (DMUs). It maximizes technological efficiency of a given unit on the condition that efficiency measures have been standardized for all units of a set. The method does not require knowing the functional relationship between results and expenditures. In turn, it is assumed that volumes of expenditures and results are above or equal to zero, but for each decision making unit at least one expenditure and one result exceed zero.

Efficiency can be optimized through decreasing expenditures to receive present results or increasing results with expenditures used at the present level. We have chosen the first solution.

The efficiency of each unit $\theta$ is determined by the radial distance from the empirical frontier of technological capability, the so called best practice frontier. It is graphically illustrated by a piecewise linear function matching the most efficient decision making units. The efficiency of units on the curve is 1 . Units below the curve are predominated by objects on the curve and their ratio is below 1 . The Charnes-Cooper transformation allows to reduce the problem to a linear programming task, which facilitates its solution.

From the point of view of returns to scale, there are several types of models. The CCR model $^{1}$ assumes constant returns to scale and a measure it allows to calculate is called total technical efficiency. If we assume variable returns to scale, the BCC model ${ }^{2}$ is applied, whose solution serves to determine purely technical efficiency - how much smaller expenditures may serve to achieve the same results.

If there is a difference between efficiency for constant and changing returns to scale, the efficiency of scale can be determined. It is calculated as follows:

1 From the names of its authors: Charnes, Cooper, Rhodes.

2 The name comes from the names of the model's authors: Banker, Charnes, Cooper. 


$$
e_{-} s_{-} v r s=\frac{e_{-} c r s}{e_{-} v r s}
$$

where:

e_s_vrs - efficiency of scale;

e_crs - technical efficiency derived from the CCR model;

e_vrs - purely technical efficiency derived from the BCC model.

If the efficiency of scale equals 1 , a given decision making unit is efficient in relation to the scale of expenditures made. Otherwise $\left(e_{-} s_{-}\right.$vrs $\left.<1\right)$, no efficiency in relation to the scale of expenditures is observed. It should, however, be kept in mind that formula (1) does not provide information on whether those are increasing or decreasing returns to scale. In order to obtain that information, the NIRS (Non Increasing Returns to Scale) model has to be calculated. Solving the NIRS model enables to receive value $e_{-}$nirs to be used to determine the area of returns to scale according to formula:

$$
e_{-} s_{-} \text {nirs }=\frac{e_{-} \text {crs }}{e_{-} \text {nirs }}
$$

Value $e \_s \_n i r s$ equal to 1 means that a unit is in the area of increasing and below 1 - in the area of decreasing - returns to scale.

Comparing the four above-described measures (i.e. e_crs, e_vrs, e_s_vrs and $e_{-}$s_nirs) offers the description of efficiency of a given unit. A DMU for which each of the above measures equals 1 is characterized by an optimum combination of expenditures and results.

In practice, $\theta$ is 1 for more than one unit; hence there are several ranking leaders. In order to unambiguously determine the most efficient unit, we use the so called super-efficiency. The name comes from the fact that its values may be above 1 . It is calculated by means of the modified CCR model. The optimum value of the objective function in the expenditure-oriented model with super-efficiency is interpreted as the minimum expenditures of competitors required to achieve results of a given decision making unit.

A classical approach to the DEA method assumes uniform efficiency of all expenditures or results. That assumption can, however, be abandoned and the so called non-radial efficiency can be computed, which assumes that partial 
efficiency in respect of a given expenditure or result may be different for each expenditure (result) with partial efficiency remaining radial [Guzik 2009, p. 201]. The calculated optimum $\hat{\theta}_{n o}$ index expresses, firstly, efficiency of unit $o$ in respect of expenditure $n$. Secondly, it determines the percentage to which expenditure $n$ should be decreased so that unit $o$ achieves one-hundred-percent efficiency in respect of that expenditure. The mean value of optimum partial efficiency indices for all expenditures is the so called Russell efficiency.

From the point of view of stability of calculations, the ratio of the number of decision making units to the number of expenditures and results is important. It is recommended [compare: Guzik 2009, p. 29] to seek the following relationship:

$$
J>\max (P \cdot R, 3(P+R))
$$

where $J$ is the number of DMUs, $P$ - the number of expenditures and $R$ - the number of results. Thus, considering 16 voivodships, the list of expenditures and results should be considerably limited.

Another factor affecting determination of the set of expenditures and results is correlations which occur among them. In the DEA method, low correlations between expenditures and results are preferred as high correlations result in a degenerated optimum solution.

Keeping the above in mind, the set of expenditures we use in the DEA method includes an index expressing the volume of domestic expenditures on research and development per 1000 of the population. Hence, we take into account the fact that voivodships differ significantly in their numbers of inhabitants. Another expenditure we have selected is personnel employed in that sector in 2012 according to voivodships. Results we have chosen are the number of granted patents and the number of granted utility models, also separately for each voivodship. Our calculations have used the CSO data.

\section{Empirical Analysis of the Efficiency of Research and Development Activity}

We have already proved that voivodships differ markedly in human and financial resources they allocate to R\&D activity. The greatest concentration of research units, personnel etc. is observed in the Mazowieckie voivodship. The other voivodships lag far behind. However, high concentration of resources does not automatically translate into their fully efficient use. That is the fundamental conclusion drawn from analysing indices of efficiency shown in Table 1 . 
Table 1. Indices of efficiency and returns to scale

\begin{tabular}{|c|c|c|c|c|}
\hline Voivodship & e_crs & e_vrs & e_s_vrs & e_s_nirs \\
\hline Dolnośląskie & 0.7358 & 1 & 0.7358 & 0.7358 \\
\hline Kujawsko-Pomorskie & 0.6887 & 0.7612 & 0.9048 & 1 \\
\hline Lubelskie & 0.3142 & 0.3664 & 0.8575 & 0.8575 \\
\hline Lubuskie & 0.1990 & 1 & 0.199 & 1 \\
\hline Łódzkie & 0.4002 & 0.4584 & 0.8730 & 0.8730 \\
\hline Małopolskie & 0.3378 & 0.3712 & 0.9100 & 0.9100 \\
\hline Mazowieckie & 0.3994 & 1 & 0.3994 & 0.3994 \\
\hline Opolskie & 1 & 1 & 1 & 1 \\
\hline Podkarpackie & 0.5345 & 0.5903 & 0.9055 & 0.9055 \\
\hline Podlaskie & 0.5837 & 0.7011 & 0.8325 & 1 \\
\hline Pomorskie & 0.2336 & 0.2626 & 0.8896 & 0.8896 \\
\hline Śląskie & 1 & 1 & 1 & 1 \\
\hline Świętokrzyskie & 1 & 1 & 1 & 1 \\
\hline Warmińsko-Mazurskie & 0.5692 & 0.6247 & 0.9112 & 1 \\
\hline Wielkopolskie & 0.4825 & 0.5414 & 0.8912 & 0.8912 \\
\hline Zachodniopomorskie & 0.5609 & 0.5900 & 0.9507 & 0.9507 \\
\hline
\end{tabular}

Source: own calculations.

Surprisingly, assuming constant returns to scale, the most efficient turned out to be solely the Opolskie, Śląskie and Świętokrzyskie voivodships. What is more, they clearly predominated over the other decision making units. The highest ranking inefficient the Dolnośląskie voivodship, was markedly below the best practice frontier. Half of voivodships showed indices not exceeding 0.55 . The lowest result was achieved by the Lubuskie voivodship. An index equal to 0.199 indicates that a voivodship should use, on average, about $80 \%$ less of held resources in order to achieve present results. Still considering constant returns to scale, other voivodships appeared to be very inefficient too. Interestingly, that group included the Mazowieckie voivodship where such results as the present ones would be obtained through reducing expenditures by as much as $60 \%$. It is a surprising observation if we 
remember how many financial and human resources are concentrated in the Mazowieckie voivodship.

The DEA method allows to compute the so called benchmarking formulas for inefficient units. A benchmark is understood as an indication of specific efficient units whose example ought to be followed in order to improve present efficiency. When feeding expenditures and results of model decision making units into the formula, we will receive new optimum technology values for an inefficient unit.

For example, a benchmarking formula for the CCR model determining an optimum technology oriented at the Lubuskie voivodship is composed of $9 \%$ of technology applied in the Opolskie voivodship and 8\% of technology used in the Swiętokrzyskie voivodship. That means that research entities of the Opolskie and Świętokrzyskie voivodships would be able to achieve results of the Lubuskie voivodship with the domestic expenditures index per 1000 of the population at PLN 13.5 instead of PLN 68.4 and with personnel employed in R\&D activity at 220 instead of 1,118 individuals.

An optimum technology oriented at the Mazowieckie voivodship would also use the technology of the Opolskie and Śląkie voivodships. In that case an optimum value of domestic expenditures would fall to the level of PLN 368.6 per 1000 of the population (empirical value of PLN 921.6). Moreover, it would be sufficient to employ 11.8 thousand instead of 37.2 thousand individuals with received results equal to the present ones.

Calculations of the model with variable returns to scale (column $e_{-}$vrs in Table 1) differ from those of the CCR model. The number of efficient voivodships went up to six, including the same three as before. The Mazowieckie voivodship turned out being efficient this time. Half of voivodships were characterized by an index not exceeding 0.66 , but predomination of the efficient DMUs still remained strong. 13 voivodships were not efficient in relation to the scale of incurred expenditures (see the $e_{-} s$ _vrs values in Table 1). Out of those thirteen, four voivodships: Kujawsko-Pomorskie, Lubuskie, Podlaskie and Warmińsko-Mazurskie, were in the area of increasing returns to scale. In their case, an additional unit of expenditure would produce more than a unit of result. Among voivodships characterized by decreasing returns to scale attention should be paid to the Zachodniopomorskie voivodship being close to the efficiency frontier. In turn, the Opolskie, Śląkie and Świętokrzyskie voivodships were model ones irrespective of an assumed model.

Results in Table 1 indicate a low level of efficient use of expenditures in the whole country. Only a few voivodships were fully efficient, while a large group 
was in the area of decreasing returns to scale. That, regrettably, indicates considerable wastage of expenditures in the R\&D sector in Poland.

Table 2. Super-efficiency indices

\begin{tabular}{|l|r|r|}
\hline \multirow{2}{*}{ Voivodship } & \multicolumn{2}{|c|}{ se_crs } \\
\cline { 2 - 3 } & absolute & \multicolumn{1}{|c|}{ relative } \\
\hline Świętokrzyskie & 2.8859 & 1 \\
\hline Śląskie & 1.7747 & 0.6145 \\
\hline Opolskie & 1.4846 & 0.5144 \\
\hline Dolnośląskie & 0.7358 & 0.2550 \\
\hline Kujawsko-Pomorskie & 0.6887 & 0.2386 \\
\hline Podlaskie & 0.5837 & 0.2023 \\
\hline Warmińsko-Mazurskie & 0.5692 & 0.1972 \\
\hline Zachodniopomorskie & 0.5609 & 0.1944 \\
\hline Podkarpackie & 0.5345 & 0.1852 \\
\hline Wielkopolskie & 0.4825 & 0.1672 \\
\hline Łódzkie & 0.4002 & 0.1387 \\
\hline Mazowieckie & 0.3994 & 0.1384 \\
\hline Małopolskie & 0.3378 & 0.1171 \\
\hline Lubelskie & 0.3142 & 0.1089 \\
\hline Pomorskie & 0.2336 & 0.0809 \\
\hline Lubuskie & 0.1990 & 0.0690 \\
\hline
\end{tabular}

Source: own calculations.

Table 2 shows super-efficiency indices (se_crs) for the expenditure-oriented CCR model. They are provided as absolute and relative values compared to the highest of them. Let us remind that, in that model, values of the objective function are interpreted as the minimum expenditures of competitors required to achieve results of a given decision making unit. The other voivodships, within the framework of the common optimum technology, would have to incur almost twice (to be precise 1.89 times) as high expenditures in order to obtain results of the Świętokrzyskie voivodship. Competitors of the weakest 
of efficient voivodships, the Opolskie voivodship, would have to make $48 \%$ higher expenditures than those that actually occurred in that voivodship to receive its results.

Yet again, we can observe strong predominance of efficient voivodships over inefficient ones. It appears, however, that there were also considerable differences among units at the efficiency frontier. Efficiency of the second in the ranking, the Śląskie voivodship, represented slightly more than $60 \%$ of the Świętokrzyskie voivodship's efficiency, while it was about 50\% for the Opolskie voivodship. Even vaster disproportions can be seen when comparing inefficient voivodships with the Swiętokrzyskie voivodship. For the Lubuskie voivodship, relative efficiency was as low as $7 \%$.

The classical approach to the DEA method assumes uniform efficiency of all expenditures or results, whereas in the non-radial model partial efficiency may be different for each expenditure or result. Then the model's objective function is the mean of partial efficiency indices. Such analyses are useful in determining which expenditures were efficiently used for a given decision making unit.

Table 3 shows optimization results for the non-radial expenditure-oriented CCR model. Column $e_{-} n r_{-}$crs contains arithmetic mean of partial efficiencies provided in two consecutive columns.

Voivodships efficient in the classical CCR model remained efficient in the model with non-radial efficiency, which is interpreted as full efficiency in terms of each expenditure. Although values of indices for inefficient voivodships changed as compared to their values in Table 1, previous relationships among them remained. Hence, the least efficient was still the Lubuskie voivodship, while the predominance of efficient voivodships became even slightly stronger. 
Table 3. Results of model with non-radial efficiency

\begin{tabular}{|c|c|c|c|c|}
\hline Voivodship & $\begin{array}{c}\text { e_nr_crs } \\
\text { (mean) }\end{array}$ & $\begin{array}{c}\text { Domestic } \\
\text { expenditures } \\
\text { per } \\
1000 \text { of the } \\
\text { population }\end{array}$ & Personnel & $\begin{array}{l}\text { Coefficient } \\
\text { of variation }\end{array}$ \\
\hline Dolnośląskie & 0.6924 & 0.7358 & 0.6489 & 0.3511 \\
\hline Kujawsko-Pomorskie & 0.6840 & 1 & 0.3680 & 0.6320 \\
\hline Lubelskie & 0.3121 & 0.3279 & 0.2962 & 0.7038 \\
\hline Lubuskie & 0.1822 & 0.1609 & 0.2034 & 0.7966 \\
\hline Łódzkie & 0.3946 & 0.4940 & 0.2951 & 0.7049 \\
\hline Małopolskie & 0.3376 & 0.3297 & 0.3454 & 0.6546 \\
\hline Mazowieckie & 0.3578 & 0.3994 & 0.3161 & 0.6839 \\
\hline Opolskie & 1 & & & \\
\hline Podkarpackie & 0.4963 & 0.7347 & 0.2579 & 0.7421 \\
\hline Podlaskie & 0.5354 & 0.7744 & 0.2964 & 0.7036 \\
\hline Pomorskie & 0.2064 & 0.1731 & 0.2397 & 0.7603 \\
\hline Śląskie & 1 & & & \\
\hline Świętokrzyskie & 1 & & & \\
\hline Warmińsko-Mazurskie & 0.5135 & 0.6908 & 0.3362 & 0.6638 \\
\hline Wielkopolskie & 0.4823 & 0.4478 & 0.5167 & 0.4833 \\
\hline Zachodniopomorskie & 0.5460 & 0.5609 & 0.5310 & 0.4690 \\
\hline
\end{tabular}

Source: own calculations.

Voivodships inefficient in the non-radial sense are inefficient in respect of at least one expenditure. Such a situation occurred in the Kujawsko-Pomorskie voivodship, which proved to be efficient in terms of domestic expenditures but inefficient in terms of personnel with that inefficiency being very high.

The other voivodships did not efficiently use both the expenditures. For half of them partial efficiency in respect of domestic expenditures per 1000 of the population did not exceed 0.5 , whereas in terms of personnel it did not exceed 0.32 . Therefore, it can be inferred that financial resources were man- 
aged better than human resources. It was a general trend rather than a strictly applicable rule as, for a few voivodships, efficiency in terms of personnel was higher. As for the partial efficiencies themselves, their remarkable diversification reflected considerable wastage of expenditures.

The last column in Table 3 shows variation coefficients of partial efficiencies. They were used to assess the degree of harmonization of expenditures for specific voivodships. They all displayed values (low values of variation coefficients are considered not to exceed 0.1), which indicated severe lack of expenditures' harmonization. Expenditures were the least harmonized in the Lubuskie voivodship but even for the Dolnośląskie voivodship the coefficient was still high.

Low efficiency values observed in models with radial efficiency did not, thus, have one cause as the reason for substantial differences among voivodships was the inefficient use of both financial and human resources.

\section{Summary}

It should be conceded that the R\&D sector situation in Poland is not good. Although research and development expenditures have been rising for several years, both the pace and amounts do not still allow to significantly reduce the distance between our country and a majority of EU countries or some other countries around the world. The manner of financing does not help either, as the bulk of funds comes from the state budget, while enterprises prefer to buy ready-made solutions abroad instead of financing research projects in Poland. Cooperation between business and science is also insufficient.

A characteristic feature of research and development activity in Poland is its strong concentration. Most research units, personnel and domestic expenditures are located in the territory of the Mazowieckie voivodship. Contrary to appearances, it is not beneficial to research and development activity. Firstly, other regions lose due to their slower development and lack of access to results of R\&D activity. Secondly, the concentration of resources in one region by no means results in their efficient use.

As we assumed in the introduction only a small group of voivodships was characterized by full efficiency of transforming expenditures into results (in terms of DEA). That was especially noticeable in the model with constant returns to scale. Moreover, the Mazowieckie voivodship did not use its expenditures efficiently at all. Anyway, low values of efficiency indices for all inefficient voivodships were clearly visible. None of them might be considered close to the efficiency frontier, which was additionally accompanied by large differences between decision making units themselves. 
The non-radial DEA model proved that neither domestic expenditures (per 1000 of the population) nor personnel employed in R\&D activity were efficiently used, to a large extent, with the former managed a little more efficiently by research units.

Certainly, it should be kept in mind that the DEA method is based on a subjective selection of expenditures and results. Changes to just some of them may produce changes in the group of efficient units. In our case, the applied models were consistent in terms of the high level of R\&D inefficiency in a majority of voivodships and substantial disproportions among them.

\section{Bibliography}

Nauka i technika w 2012 r. (2013), raport przygotowany przez Urząd Statystyczny w Szczecinie, Informacje i opracowania statystyczne, Warszawa.

Adamczyk A. (2013), Inwestycje w badania i rozwój przedsiębiorstw w świetle badań ankietowych, „Wiadomości Statystyczne”, nr 1, ss. 57-65.

Andersen P., Petersen N.C. (1993), A procedure for ranking efficient units in Data Envelopment Analysis, "Management Science", 39 (10).

Baczko T., Puchała-Krzywina E., Szyl M. Paczkowski T. (2013), Raport o największych inwestorach $w$ badania i rozwój $w$ Polsce w 2012 roku, Instytut Nauk Ekonomicznych PAN, Warszawa.

Banker R., Charnes A., Cooper W.W. (1984), Some Models for Estimating Technical and Scale Efficiencies in Data Envelopment Analysis, "Management Science", 30, ss. $1078-1092$.

Charnes A., Cooper W.W., Rhodes E. (1978), Measuring the efficiency of decision making units, "European Journal of Operational Research", 2, ss. 429-444.

Guzik B. (2009), Podstawowe modele DEA w badaniu efektywności gospodarczej i spotecznej, Wydawnictwo Uniwersytetu Ekonomicznego w Poznaniu, Poznań.

Kucharski A. (2009), Badanie efektywności wybranych funduszy inwestycyjnych w przededniu kryzysu, P. Karpuś, J. Węcławski (red.), Rynek finansowy w erze zawirowań, Wyd. UMCS, Lublin, ss. 153-162.

Prędki A. (2008), Problematyka określania typu efektu skali za pomoca metody DEA, Badania operacyjne metody i zastosowania, red. J.B. Gajda, A. Kucharski, Wydawnictwo Uniwersytetu Łódzkiego, Łódź, ss. 321-334. 